\title{
BIBLIOGRAPHIE/ BIBLIOGRAPHY
}

\author{
Die nachfolgende Literaturauswahl ist erstellt in Zusammenarbeit mit der Übersee-Doku- \\ mentation des Deutschen Übersee-Instituts Hamburg*.
}

The following selected Bibliographie has been compiled in cooperation with the Overseas Documentation of the German Overseas Institute, Hamburg**.

\section{AFRIKA/AFRICA}

Alkazaz, Aziz, Die arabischen Staaten und die Länder der Dritten Welt, in: Nord-Süd aktuell (Hamburg) 3/ 1988, 348-362

African political systems/ed. by M. Fortes (u.a.). - London (u.a.): KPI, 1987

Anyangwe, Carlson, The legal aspect of bilingualism, in: Revue Science et Technique: Série Sciences Humaines (Yaounde). - 3 (Juillet-décembre 1985) 3-4, S. 5-14

Babadji, Ramdane, Le fonctionnaire et l'Etat en Algérie: de l'obligation de réserve à l'obligation de l'allegeance, in: Revue Algérienne des Sciences Juridiques, Economiques et Politiques (Alger). - 25 (juin 1987) 2, S. 335-345

Boumakani, Benjamin, Les aspects nouveaux du pouvoir réglementaire en droit public congolais, in: Revue juridique et politique (Paris). - 41 (juillet-septembre 1987) 3, S. 185-198

Davis, Dennis, Das Recht im Apartheidstaat, Shaidi, Leonard P.: Jugendrecht und Strafvollzug in Tansania: Leunmi, Benjamin: Jugendkriminalität in Afrika, in: Der Überblick (Stuttgart). - 23 (September 1987) 3, S. 31-39

Delouvroy, Jacques, Le developpement du droit judiciaire a Burkina Faso, in: Revue juridique et politique (Paris). 41 (juillet-septembre 1987) 3, S. 228-244

Duignan, Peter; Gann, L.H., South Africa, aus: Politics and government in African states 1960-1985. - London (u.a.), Croom Helm, 1986, S. 283-344

Hinz, Manfred O., Hiemstras Namibia Verfassung: zwischen Staatsstreich und Public Relations, in: Informationsdienst Südliches Afrika (Bonn) (November 1987) 7, S. 27-30

Jaster, Robert S., The rocky road to Lancaster House: lesson from the Rhodesian conflict, in: South Africa International (Johannesburg). - 18 (Oktober 1987) 2, S. 107-129

Jisheng, Xia, Evolution of South Africa's racist constitutions and the 1983 constitution, in: Issue (Los Angeles/Cal.). - 16 (1987) 1, S. 18-23

Liebenow, J. Gus, Liberia: the quest for democracy. - Bloomington/Ind. (u.a.): Indiana Univ. Pr., 1987. - XIII, S. 336

Lijphart, Arend, Power-sharing in South Africa/ Institute of International Studies, University of Calif ornia. - Berkeley/Cal.: Univ. Pr., 1985. - X, S. 178

Mahalu, Costa Ricky, The teaching of international law in anglophonic Afria, in: Archiv des Völkerrechts (Tübingen). - 24 (1986) 2, S. 196-214

Malinga, Phineas, Indaba for a quiet capitalist life, in: African Communist (London). - (Third Quarter 1987) 110, S. $72-79$

Morobe, Murphy, Towards a people's democracy, in: South Africa International (Johannesburg). - 18 (July 1987) 1, S. $30-38$

* Diese Bibliographie dienst ausschließlich der Information. Die angegebenen Titel können von VRÜ und der Übersee-Dokumentation nicht geliefert werden.

** This Bibliographie serves information purposes only. Neither VRÜ nor the Overseas documentation can supply any of the titles listed. 
Nigeria: towards 1992, in: West Africa (London) - P. 1-5, 3.-31. 8. 1987

Nowak, Manfred, Die Menschenrechtssituation in Südafrika, in: Aus Politik und Zeitgeschichte (Bonn). - (1986) $29 \cdot 30$, S. $16 \cdot 25$

Petzold, Siegfried, Wesen und Organisation der Staatsmacht in der Volksrepublik Angola, in: Staat und Recht (Berlin/ Ost). - 33 (1984) 3, S. 220-229

Picard, Louis A., The politics of development in Botswana: a model for success? - Boulder/Colo. (u.a.)- Rienner, 1987, S. 298

Popular struggles for democray in Africa/ed. by Peter Anyang' Nyong'o/ The United Nations University, Third World Forum. - London (u.a.): Zed Books, 1987

Ropp, Klaus von der, , A political initiative for South Af rica: a (West) German view, in: Politikon (Florida/RSA). 14 (June 1987) 1, S. 3-14

van Rouveroy van Nieuwaal, Emile A.B., Chiefs and African States, in: Journal of Legal Pluralism and Unofficial Law, Groningen 25/ 26 (1987), S. 1.46

Serapiao, Luis Benjamin; Haile, Semere, International law and self-determination: the case of Eritrea - the roots of the Ethiopia-Eritrea conflict, in: Issue (Los Angeles/ Cal.). - 15 (1987), S. 3-17

Siddiqui, Rukhsana A., International law and human rights in South Africa, in: Africa Quarterly (New Delhi). - 24 (1987) 1-2, S. 6-21

Skalnik, Peter, On the Inadequacy of the Concept of the "Traditional State", in: Journal of Legal Pluralism and Unofficial Law, Groningen 25/ 26 (1987), S. 301-325

Staat, Verwaltung und Recht in Afrika 1960-1985: Beiträge zur Verwaltungswissenschaftlichen Arbeitstagung 1985 des Forschungsinstituts für öffentliche Verwaltung bei der Hochschule für Verwaltungswissenschaften Speyer/ hrsg. von Hans F. Illy (u.a.). - Berlin/ West: Duncker \& Humblot, 1987

Sulaiman, Ibraheem, Which constitution?, in: Africa Events (London) - 3 (December 1987) 12, S. 29-42

Tetzlaff, Rainer, Weltbank und Währungsfonds, in: Afrika mit ihrem Latein am Ende?, in: Nord-Süd aktuell (Hamburg) $3 / 1988$, S. 334-336

Theodoropolos, Christos, Legal dualism in Namibia: the present as history, in: Eastern Africa Law Review (Dar es Salaam). - 15 (1982), S. 20-65

Van Wyk, Dawid, Indaba - The process of real negotiation, in: South Africa International (Johannesburg). - 18 (October 1987) 2, S. 99-106

The constitution, in: Social Change and Development (Harare). - 7 (1987) 3. S. 1-13, 16-17, 22-31

Zone économique exclusive: un appel à la coopération (Emmanuel Aloa Eteme) in: Bulletin du C.N.C.C. (Douala). (juin 1987) Hors-serie 4, S. 1-48

\section{ASIEN/ASIA}

Bean, Clive S., Electoral law, electoral behaviour and electoral outcomes: Australia and New Zealand compared, in: Journal of Commonwealth and Comparative Politics 24 (1986), S. 57-73

Bechthold, Kurt, Das australische Familiengericht: eine Darstellung mit Bezügen zur Familiengerichtsbarkeit der Bundesrepublik Deutschland, Frankfurt a. Main 1986, S. 313

Bergin, Anthony, Recent developments in Australia's Antarctic policy, in: Marine Policy 9 (1985), S. 18 ff. (S. 12)

Bonney, Norman, The politics and finance of provincial government in Papua New Guinea, Canberra 1986

Burns, John P., Immigration from China and the future of Hong Kong, in: Asian Survey (Berkeley/ Cal.). - 27 (June 1987) 6, S. 661-682

Duscha, Waldemar, Technologietransfer in die Volksrepublik China durch Wirtschaftskooperation: Bestimmungsgründe, Formen, Standorte und Wirkungen. - Hamburg 1987. - XXI, S. 307

Energy, security and economic development in East Asia/ ed. by Ronald C. Keith. - London (u.a.): Croom Helm, 1986. - S. 303

Enkhsaikhan, Jargalsaikhany, Ensuring peace in Asia and the Pacific: the Mongolian initiative, in: Asian Survey (Berkeley/Cal.). - 25 (October 1985) 10, S. 1031-1038

Falkenheim, Victor C., The limits of political reform, in: Current History (Philadelphia/ Pa.). - 86 (September 1987) 521, S. 261-265, 279-281

Ghai, Yash P., The Westminster Model in the South Pacific: the case of Western Samoa, in: Public Law (1986), S. 597-621

Hoadley, Steve, Neuseelands Politik der Kernwaffenfreiheit: ihre Entwicklung und ihre politischen Auswirkungen, in: Europa-Archiv 42 (1987) 20, S. 597-604 
Indebtedness and growth in developing countries, Armin Gutowski: Manfred Molthus; Dietrich Kebschull, Hamburg: Verl. Weltarchiv, 1986

Kim Jung-gun, Reflections on the attitude on North Korea toward the law of the Sea: Asian Perspective (Seoul). - 9 (1985) 1, S. 57-94

Mewongukote, Boonsri, Wahlrecht in Thailand unter Berücksichtigung der Wahlrechtsgrundsätze im deutschen Verfassungsrecht. - Heidelberg, 1986, S. 257

Miners, N.J., Plans for constitutional reform in Hong Kong, 1946-52, in: The China Quarterly, 1986, S. 463-482

Myers, Ramon H., Political theory and recent political development in the Republic of China, in: Asian Survey (Berkeley/ Cal.). - 27 (September 1987) 9, S. 1003-1022

Nie Youxi, Die Zukunft Macaos: Kommentar zu dem chinesisch-portugiesischen Abkommen vom 13. April 1987

Poljakov, V., A patent system set up in China, in: Eastern Affairs (1986), S. 111-118

Roff, Sue Rabbitt, New Caledonia: decolonisation and denuclearisation in: the Pacific, in: Third World Quarterly. - 8 (1986) 2, S. 621-638

Suryadinate, Leo, Pribumi Indonesians, the Chinese minority and China: a study of perceptions and politics - 2 nd ed. - Singapore (u.a.): Heinemann Asia, 1986 - S. 241

Vaidya, Tulasi Ram; Manandhar, Tri Ratna, Crime and punishment in Nepal: a historical perspective. - Kathmandu: Vaidya (u.a.), 1985. - S. 302

Verney, Douglas $V$., The limits to political manipulation: the role of the governors in India's administrative federalism 1950-84, in: Journal of Commonwealth and Comparative Politics (Leicester). - 24 (July 1986) 2, S. 169-196

Visiting mission to observe the plebiscite in Palau, Trust Territory of the Pacific Islands, February 1986: report/ United Nations Trusteeship Council. - New York/ N.Y. 1986, S. 48

Wundersitz, Joy and Gale, Fay, Disadvantage and Discretion: The Results for Aboriginal Youth in Relation to the Adjournment Decision, Adelaide Law Rev. (Adelaide) 11 (1988), S. 348-358

Yoon Hong-key, Maori mind, Maori land: essays on the cultural geography of the Maori people from an outsider's perspective. - Berne (u.a.) 1987 II, S. 138

\section{LATEINAMERIKA/LATIN AMERICA}

Cortazar, Rene, La no-transición a la democracia en Chile, y el plebiscito de 1988,in: Estudios CIEPLAN (Santiago de Chile) 1987,22 , S. 111-128

Figallo, Guillermo, Las comunidades campesinas y nativas en la constitución politica, in: Socialismo y Participación (Lima) 1987,39 , S. 81-89

Franco, Wellington Moreira, Probleme der Umwelt in Brasilien, in: Deutsch-Brasilianische Hefte (Bonn) 26 (1987) 5, S. 300-309

Garcia Belaunde, Domingo, Una democracia en transición: las elecciones peruanas de 1985, in: Sintesis (Madrid) 1987 , 3, S. $167-208$

Garcia Sayan, Diego, Peru: estados de excepcion y regimenjuridico, in: Sintesis (Madrid) 1987, 3, S. 274-296

Gonzalez, Raul, Policias, jueces y subversion, in: Que Hacer (Lima) 1988, 52, S. 32-39

Hörmann, Marion, Peruanischer Weg aus der Schuldenkrise?, in: Nord-Süd aktuell, Hamburg, 3/ 1988, 322-334

Kokott, Juliane, Völkerrechtliche Beurteilung des argentinischen Gesetzes 23-521 über die Gehorsamspflicht (obediencia debida), in: Zeitschrift für Ausländisches Öffentliches Recht und Völkerrecht (Stuttgart) 47 (1987) 3, S. 506-536

Padilla, Amado M.; Gomas-Diaz, Lillian, Miedo y represion politica en Chile, in: Revista Latinoamericana de Psicologia (Bogota) 19 (1987) 2, S. 135-146

Smulowitz, Catalina, Reforma Constitucional y consolidación democratica en la Argentina: fundación de un nuevo juego o retorno a la instabilidad de reglas, in: Cuadernos del CLAEH (Montevideo) 12 (1987) 43, S. 69-76

Sukup, Viktor, Argentinien unter Alfonsin: ist die Demokratisierung gesichert?, in: Blätter für deutsche und internationale Politik (Köln) 32 (1987) 3, S. 368-375

Urioste, Fernando, Las democracias y la impunidad, in: Cuadernos de Marcha (Montevideo) 3 (1988) 30, S. 6-13 


\section{VORDERER ORIENT/NEAR AND MIDDLE EAST}

Ahmed, Munir, D., Frauenfrage und Islam, aus: der Nahe und Mittlere Osten. Opladen: Leske und Budrich, 1988, Bd. 1, S. 521-531

Amin, Sayed Hassan, Law and justice in contemporary Yemen: the People's Democratic Republic of Yemen and the Yemen Arab Republic, Glasgow: Royston, 1987, V, S. 159

Bakhash, Shaul, Islam and social justice in Iran, aus: Shi'ism, resistance, and revolution/ ed. by Martin Kramer. Boulder/ Col.: Westview Pr. (u.a.), 1987, S. 95-115

Baumgarten, Helga, Befreiungs- und Widerstandsorganisationen, aus: Der Nahe und Mittlere Osten. Opladen: Leske u. Budrich, 1988, Bd. 1, S. 295-301

Bhuiyan, Rabia, The legal rights of Muslim women in marriage and divorce. - Dhaka: Women for Women, 1986, 12 S., Women for Women?

Blaschke, Nasreen, Stemming a tide of human misery, in: Middle East (London), July 1987, 153, S. 17-19

Brichta, Avraham; Zalmanovitsch, Yair, The prospects for presidential government in Israel: a case study in the possibility of institutional transference, in: Comparative Politics (New York/N.Y.). - 19 (October 1986) 1, S. 57-68

Crainkar, Louise; Abu-Shakran, Jan, A critique of the U.S. State Department's 1986 country report on human rights practices in 1967 Israeli-occupied Palestinian territories, in: Journal of Palestine Studies (Washington D/C). - 17 (Autumn 1987) 1/65, S. 89-96

Duran, Khalid, Die Wiederbelebung der islamischen Rechts- und Gesellschaftsordnung, aus: Der Nahe und Mittlere Osten. Opladen: Leske u. Budrich, 1988, Bd. 1, S. 555-565

Ebert, Hans Georg; Fürtig, Henner; Müller, Hans Georg, Die Islamische Republik Iran/hrsg. von Günter Barthel. Köln: Pahl-Rugenstein, 1987, S. 502

Elwan, Omaia, Gesetzgebung und Rechtssprechung, aus: Der Nahe und Mittlere Osten. Opladen: Leske u. Budrich, 1988 , Bd. 1. S. 221-254

Farouk-Sluglett, Marion; Sluglett, Peter, From gang to elite: the Iraqui Ba'th Party's consolidation of power, 19681975, in: Peuples Méditerranéens (Paris), juillet-septembre 1987) 40, S. 89-114

Hippler, Jochen; Lueg, Andrea, Gewalt als Politik: Terrorismus und Intervention im Nahen Osten; Darstellung und Dokumente/ hrsg. vom Institut für Internationale Politik, Köln: Pahl-Rugenstein, 1987, S. 244

Human rights in the Arab World/the Arab Organisation for Human Rights, in: IFDA Dossier (Nyon) (NovemberDecember 1987) 62, S. 63-72

Jafri, H.A.S., Evolution of Afghanistan as an independent state, in: India Quarterly (New Delhi), 42 (April-June 1986) 2, S. 130-141

Kramer, Heinz, Der türkische EG-Beitrittsantrag und der "griechische Faktor", in: Europa-Archiv (Bonn). - 42 (10. November 1987) 21, S. 605-614

Kruse, Hans, Öffentliche Verwaltung, aus: Der Nahe und Mittlere Osten. Opladen: Leske u. Budrich, 1988, Bd. 1 S. $211-219$

Mahdi, $F$., Les limites du dévelopment: remarques sur l'Etat et la société en Irak

Maley, William, Political legitimation in contemporary Afghanistan, in: Asian Survey (Berkeley/ Cal.) 27, June 1987, 6, S. 705-725

Mattes, Hanspeter, Die innenpolitische Entwicklung 1969-1986, aus: Libyen/hrsg. von Christian Operschall und Charlotte Teuber, Wien: Promedia, 1987, S. 31-47

Milan, Shapour S., The legal status of the Persian Gulf as a semi-enclosed sea, in: Archiv des Völkerrechts (Tübingen), 25 (1987) 1, S. 92-105

Robert, Rüdiger, Legitimitäts- und Stabilitätsprobleme politischer Systeme, aus: Der Nahe und Mittlere Osten. Opladen: Leske und Budrich, 1988. - Bd. 1, S. 187-194

Rogers, Tom, Afghan refugees and the stability of Pakistan, in: Survival (London), 29 (September-Oktober 1987), 5, S. 416-429

Scheffler, Thomas, Politische und gesellschaftliche Stellung von Minderheiten, aus: Der Nahe und der Mittlere Osten. Opladen: Leske u. Budrich, 1988, Bd. 1, S. 501-510

Shaikh, Farzana, Islam and the quest for democracy in Pakistan, in: Journal of Commonwealth and Comparative Politics (Leicester) 24 (March 1986) 1, S. 74-92

Wiemer, Reinhard, Regierungen, Parlamente, Parteien und Wahlen, aus: Der Nahe und Mittlere Osten. Opladen: Leske u. Budrich, 1988, Bd. 1, S. 195-210

Woyke, Wichard, Griechisch-türkischer Konflikt, aus: Der Nahe und Mittlere Osten. Opladen: Leske u. Budrich, 1988, Bd. 1, S. 739-746

Zouaimia, Rachid, Remarques critiques sur la mutation des structures périphériques de l'Etat en Algérie, in: Revue Algérienne des Sciences Juridiques, Economiques et Politiques (Alger), Juin 1986, 2, S. 291-320 